\title{
PENGARUH KUALITAS PELAYANAN TERHADAP KEPUASAN PELANGGAN, Studi kasus pada perusahaan JNE Cabang Padang
}

\author{
Mohd. Farid Tiza, Febsri Susanti \\ Sekolah Tinggi Ilmu Eknomi "KBP" \\ febsrisusanti@akbpstie.ac.id
}

\begin{abstract}
The objective of the research to analyze the influence of each tangible varible $(X 1)$ empathy $\left(X_{2}\right), \quad$ reliability $\left(X_{3}\right)$, responsiveness $\left(X_{4}\right)$ dan assurance $\left(X_{5}\right)$ to customer satisfaction ( $Y$ ) in JNE Branch Company of Ulak Karang of Padang. Data collection of research through questionnaire method to 80 customers JNE Branch Ulak Karang Padang with purposive sampling method to know the responses of respondents to each - each variable. Quantitative analysis includes the validity and reliability test, descriptive analysis, classic assumption test including normality test, test heterocedasticity, multicollinearity test, hypothesis testing via the T test. Data analysis technique used is multiple linear regression analysis . Based on this research, obtained regression equation $Y=6.703+$ $0.751 X_{1}+0.342 X_{2}+0.551 X_{3}+1.037 X_{4}+0.916 X_{5}+e$, that tangible $(X 1)$, empathy $\left(X_{2}\right), \quad$ reliability $\left(X_{3}\right)$, responsiveness $\left(X_{4}\right)$ dan assurance $\left(X_{5}\right)$ of significant positive customer satisfaction $(Y)$ in JNE Branch Company of Ulak Karang of Padang.
\end{abstract}

Keyword : Tangible, Empathy, Reliability, Responsiveness, Assurance and Customer Satisfaction

\section{PENDAHULUAN}

\section{Latar Belakang}

Dewasa ini persaingan dalam dunia bisnis sudah semakin tajam, para pemasar dituntut tidak hanya meningkatkan kualitas produk tetapi juga kualitas pelayanan untuk bisa tampil sebagai pemenang dalam persaingan. Dimana produk-produk sejenis sudah semakin tipis perbedaannya dalam hal kualitas, maka yang menjadi kunci utama untuk menjadi pemenang dalam persaingan tersebut adalah kualitas pelayanan yang diberikan perusahaan kepada para pelanggan.

Kini semakin disadari bahwa kualitas pelayanan dan kepuasan pelanggan merupakan aspek vital dalam rangka bertahan dalam bisnis dan memenangkan persaingan. Survive tidaknya suatu perusahaan ditentukan oleh kemampuan perusahaan itu sendiri dalam memberikan pelayanan yang memuaskan kepada para pelanggannya. Kepuasan pelanggan bisa menjadi senjata andalan untuk tampil sebagai pemenang dalam persaingan tetapi bisa juga sebaliknya, dimana hal itu bisa menjadi bumerang yang dapat menghancurkan posisi perusahaan dalam dunia bisnis yang semakin kompleks.

Pihak manajemen perusahaan dituntut untuk selalu memperbaiki kualitas 
pelayanannya

dengan

selalu memperhatikan apa yang menjadi kebutuhan dan harapan dari pelanggannya. Bagaimana mereka merancang pelayanan mereka terhadap pelanggan sehingga para pelanggan selalu merasa terpuaskan terhadap produk atau jasa yang ditawarkan perusahaan tersebut. Semuanya itu perlu ditempuh oleh perusahaan untuk mencapai profitabilitas yang tinggi sehingga perusahaan dapat terus tumbuh dan berkembang sesuai dengan tuntutan persaingan dan bisa menjadi pemimpin pasar yang tangguh. Untuk dapat memberikan kepuasan kepada pelanggan, perusahaan dituntut untuk dapat bersaing dengan perusahaan-perusahaan lain. Dalam persaingannya dengan perusahaan jasa pengiriman lainnya, JNE telah memberikan pelayanan secara maksimal kepada para pelanggannya. Walaupun JNE mempunyai keunggulan tersendiri dalam era persaingan, tetapi perlu disadari pula bahwa perusahaan-perusahaan jasa pengiriman lainnya juga memiliki keunggulan-keunggulan yang perlu diperhitungkan. Secara umum dapat dikatakan bahwa pada dasarnya keinginan para pelanggan yang berhubungan dengan jasa pengiriman adalah mengharapkan sesuatu yang lebih baik dan bermanfaat yaitu cepatnya kedatangan barang yang dikirim dan amannya pengiriman barang. Sebagai gambaran dapat dikemukakan pertimbangan-pertimbangan pelanggan yang berhubungan dengan perusahaan pengiriman antara lain; Cepatnya pengiriman barang, Lokasi menyangkut kemudahan jangkauan Pelayanan, menyangkut perlakuan yang diterima, Keselamatan atau keamanan akan barang. JNE Cabang Padang dengan sejumlah kantor cabang pembantu telah berusaha memenuhi semua faktor atau unsur-unsur yang menjadi pertimbangan para pelanggan, namun perusahaan belum mengetahui bagaimana penilaian para pelanggan terhadap JNE. Dengan fenomena tersebut penulis berusaha untuk mengetahui tentang tanggapan para pelanggan terhadap kualitas pelayanan JNE Cabang Padang. Dari tanggapan tersebut dapat diketahui kelebihan dan kekurangan JNE Cabang Padang sehingga dapat dievaluasi apakah strategi pemasaran yang selama ini diterapkan oleh JNE Cabang Padang sudah sesuai atau perlu dilakukan perubahan sehingga dicapai target yang diharapkan.

Untuk mengetahui sejauh mana kemampuan JNE memberikan kepuasan melalui pelayanannya, diperlukan riset pemasaran. Informasi dari hasil riset pemasaran tersebut bertujuan mengetahui sikap dan perilaku para pelanggan terhadap apa yang paling berpengaruh dalam pengambilan keputusan menjadi pelanggan JNE Cabang Padang.

Untuk melakukan pengukuran kualitas pelayanan, menurut Parasuraman (dikutip dalam Tjiptono, 2012:26) dapat digunakan dimensi-dimensi kualitas pelayanan, yaitu: bukti langsung (tangibles), kehandalan (reliability), daya tanggap (responsiveness), jaminan (assurance) dan empati (emphaty). Pengukuran ini dikenal sebagai service quality model. Pelayanan menekankan pada aspek kepuasan konsumen sehingga dapat menciptakan kesetiaan atau loyalitas kepada perusahaan yang telah memberikan kualitas pelayanan yang memuaskan.

Mengingat peran yang cukup strategis dari kepuasan konsumen terhadap kelangsungan hidup perusahaan, penulis sangat tertarik untuk mengadakan penelitian terhadap kualitas pelayanan yang diduga mempengaruhi kepuasan konsumen, maka dalam penelitian ini penulis mengambil judul "PENGARUH KUALITAS PELAYANAN TERHADAP KEPUASAN PELANGGAN", Studi kasus pada perusahaan JNE Cabang Ulak Karang Padang.

\section{Rumusan Masalah}

Rumusan masalah pada penelitian ini adalah :

1. Bagaimana pengaruh tangible terhadap kepuasan pelanggan JNE Cabang Ulak Karang Padang? 
2. Bagaimana pengaruh emphaty terhadap kepuasan pelanggan JNE Cabang Ulak Karang Padang?

3. Bagaimana pengaruh reliability terhadap kepuasan pelanggan JNE Cabang Ulak Karang Padang?

4. Bagaimana pengaruh responsiveness terhadap kepuasan pelanggan JNE Cabang Ulak Karang Padang?

5. Bagaimana pengaruh assurance terhadap kepuasan pelanggan JNE Cabang Ulak Karang Padang?

\section{Manfaat Penelitian}

a. Manfaat teoritis

1. Dapat memperkaya konsep dan teori yang mendukung perkembangan ilmu pengetahuan manajemen pengaruh kepuasan konsumen.

2. Sumbangan pemikiran untuk bahan referensi yang nantinya akan memberikan perbandingan dalam melakukan penelitian yang sama dimasa yang akan datang .

3. Penelitian ini diharapkan dapat menambah pengetahuan baik kalangan akademis (mahasiswa) maupun masyarakat umum terutama yang berkaitan tentang loyalitas konsumen.

b. Manfaat praktis

1. Bagi perusahaan, kegunaan penelitian ini dapat memberikan masukan bagaimana pengaruh kualitas pelayanan dapat mempengaruhi kepuasan konsumen sehingga menciptakan loyalitas dengan begitu perusahaan dapat lebih mengerti keinginan konsumen sehinggaJNE cabang ulak karang padang menjadi tambah lebih baik lagi.

2. Bagi manajemen perusahaan ini diharapkan dapat membantu perusahaan mendapatkan gambaran tentang demografis dan kebutuhan penumpang sehingga dapat dibentuk sebuah strategi yang efektif untuk mempertahankanya.
3. Bagi pihak lain hasil penelitian dapat memberikan informasi awal dan referensi tambahan bagi penelitian penelitian selanjutnya yang berada dalam ruang lingkup yang sama.

\section{METODOLOGI PENELITIAN}

Jenis penelitian ini adalah penelitian deskriptif dengan menggunakan pendekatan kuntitatif. Populasi dalam penelitian ini adalah seluruh Seluruh pelanggan JNE cabang ulak karang padang tahun 2017 sebanyak 660 orang, berdasarkan banyak pelanggan JNE cabang ulak karang padang. Pengumpulan data penelitian melalui metode kuesioner terhadap 80 orang pelanggan JNE Cabang Ulak Karang Padang dengan metode purposive sampling. Analisis kuantitatif meliputi uji validitas dan reliabilitas, analisa deskriptif, uji asumsi klasik meliputi uji normalitas, uji multikolinearitas, uji heterokedastisitas, uji multikolinearitas, uji hipotesis lewat uji T..Teknik analisis data yang digunakan adalah analisa regresi linear berganda.

\section{HASIL DAN PEMBAHASAN}

\section{Uji Asumsi Klasik}

Hasil normalitas penelitian dapat dilihat pada tabel berikut:

Tabel 1.

Hasil Pengujian Normalitas Data

\begin{tabular}{|c|c|c|c|}
\hline $\begin{array}{c}\text { Variab } \\
\text { el }\end{array}$ & $\begin{array}{c}\text { Asymp. } \\
\text { Sig. (2- } \\
\text { tailed) }\end{array}$ & Alpha & $\begin{array}{c}\text { Keteran } \\
\text { gan }\end{array}$ \\
\hline $\begin{array}{c}\text { Tangibl } \\
\text { e }\end{array}$ & 0,097 & 0,05 & Normal \\
\hline $\begin{array}{c}\text { Empath } \\
\text { y }\end{array}$ & 0,096 & 0,05 & Normal \\
\hline $\begin{array}{c}\text { Reliabil } \\
\text { ity }\end{array}$ & 0,146 & 0,05 & Normal \\
\hline $\begin{array}{c}\text { Respon } \\
\text { sivenes } \\
\text { s }\end{array}$ & 0,053 & 0,05 & Normal \\
\hline
\end{tabular}




\begin{tabular}{|c|c|c|c|}
\hline $\begin{array}{c}\text { Assuran } \\
\text { ce }\end{array}$ & 0,143 & 0,05 & Normal \\
\hline $\begin{array}{c}\text { Kepuas } \\
\text { an } \\
\text { Pelangg } \\
\text { an }\end{array}$ & 0,406 & 0,05 & Normal \\
\hline
\end{tabular}

Berdasarkan tabel di atas diketahui bahwa nilai signifikan (Sig) diatas nilai ( $\alpha$ $=0,05)$. Dengan demikian dapat dikatakan bahwa semua variabel peneltian yang diteliti sudah berdistribusi normal, dan selanjutnya analisis regresi dapat dilanjutkan karena data telah normal.

\section{Uji Multikolineritas}

Tabel 2.

Hasil Uji Multikolineritas

\begin{tabular}{|c|c|c|l|}
\hline $\begin{array}{c}\text { Variabel } \\
\text { bebas }\end{array}$ & $\begin{array}{c}\text { Toleranc } \\
\mathbf{e}\end{array}$ & VIF & \multicolumn{1}{|c|}{ Keterangan } \\
\hline Tangible & 0.326 & 3.071 & $\begin{array}{l}\text { Tidak } \\
\text { Multikolonierit } \\
\text { as }\end{array}$ \\
\hline $\begin{array}{c}\text { Empathy } \\
\text { ty } \\
\text { Reliabili }\end{array}$ & 0.348 & 2.870 & $\begin{array}{l}\text { Tidak } \\
\text { Multikolonierit } \\
\text { as }\end{array}$ \\
\hline $\begin{array}{c}\text { Responsi } \\
\text { veness }\end{array}$ & 0.799 & 1.252 & $\begin{array}{l}\text { Tidakolonierit } \\
\text { Multikolonierit } \\
\text { as }\end{array}$ \\
\hline $\begin{array}{c}\text { Assuran } \\
\text { ce }\end{array}$ & 0.524 & 1.910 & $\begin{array}{l}\text { Tidak } \\
\text { Multikolonierit } \\
\text { as }\end{array}$ \\
\hline
\end{tabular}

Tabel diatas menunjukkan bahwa semua variabel independen (tangible, empathy, reliability, responsiveness dan assurance) mempunyai nilai VIF yang cukup kecil, dimana semuanya berada dibawah 10 dan nilai tolerance lebih dari 0,1 . Hal ini mengindikasikan bahwa model ini terbebas dari masalah multikoloniearitas, yang berarti bahwa semua variabel tersebut dapat digunakan sebagai variabel yang saling indenpenden.

3. Uji Heteroskedastisitas

Tabel 3.

Hasil Uji Heteroskedastisitas

\begin{tabular}{|c|c|c|c|}
\hline Variabel & Sig & $\begin{array}{c}\text { Alph } \\
\text { a }\end{array}$ & Keterangan \\
\hline Tangible & 0.112 & 0,05 & $\begin{array}{c}\text { Tidak } \\
\text { Heteroskedastisit } \\
\text { as }\end{array}$ \\
\hline Empathy & 0.305 & 0,05 & $\begin{array}{c}\text { Tidak } \\
\text { Heteroskedastisit } \\
\text { as }\end{array}$ \\
\hline Reliability & 0.587 & 0,05 & $\begin{array}{c}\text { Tidak } \\
\text { Heteroskedastisit } \\
\text { as }\end{array}$ \\
\hline $\begin{array}{c}\text { Responsiv } \\
\text { eness }\end{array}$ & 0.053 & 0,05 & $\begin{array}{c}\text { Tidak } \\
\text { Heteroskedastisit } \\
\text { as }\end{array}$ \\
\hline Assurance & 0.675 & 0,05 & $\begin{array}{c}\text { Tidak } \\
\text { Heteroskedastisit } \\
\text { as }\end{array}$ \\
\hline
\end{tabular}

Berdasarkan tabel diatas pada masing-masing variabel diperoleh nilai sig $>0,05$ artinya tidak terdapatnya gejala heteroskedastisitas 
4. Analisis Regresi Berganda

Tabel 4.

Analisis Regresi Berganda

\begin{tabular}{|c|c|c|c|c|}
\hline \multirow[b]{2}{*}{ Model } & \multicolumn{2}{|c|}{$\begin{array}{l}\text { Unstandardize } \\
\text { d Coefficients }\end{array}$} & \multirow{2}{*}{$\begin{array}{c}\begin{array}{c}\text { Standardiz } \\
\text { ed } \\
\text { Coefficien } \\
\text { ts }\end{array} \\
\\
\text { Beta }\end{array}$} & \multirow[b]{2}{*}{ Sig. } \\
\hline & B & $\begin{array}{l}\text { Std. } \\
\text { Error }\end{array}$ & & \\
\hline $\begin{array}{c}1 \text { (Consta } \\
\text { nt) }\end{array}$ & 6.703 & 1.330 & & .000 \\
\hline $\begin{array}{c}\text { Tangibl } \\
\mathrm{e}\end{array}$ & .751 & .078 & .349 & .000 \\
\hline $\begin{array}{c}\text { Emphat } \\
y\end{array}$ & .342 & .082 & .118 & .000 \\
\hline $\begin{array}{c}\text { Reliabil } \\
\text { ity }\end{array}$ & .551 & .102 & .190 & .000 \\
\hline $\begin{array}{c}\text { Respon } \\
\text { sivenes } \\
\text { S }\end{array}$ & 1.037 & .061 & .392 & .000 \\
\hline $\begin{array}{l}\text { Assuran } \\
\text { ce }\end{array}$ & .916 & .061 & .432 & .000 \\
\hline
\end{tabular}

Dari data diatas dapat dibuat persamaan regresi berganda sebagai berikut :

$$
\begin{aligned}
Y= & 6.703+0.751 X_{1}+0.342 X_{2} \\
& +0.551 X_{3}+1,037 X_{4}+0,916 X_{5}+e
\end{aligned}
$$

Dari persamaan tersebut dapat diambil kesimpulan bahwa:

Koefisien regresi tangible bernilai positif. Berarti ada pengaruh positif antara tangible terhadap kepuasan pelanggan. Maksudnya jika tangible semakin baik maka semakin meningkatkan kepuasan pelanggan.

Koefisien regresi empathy bernilai positif. Berarti ada pengaruh positif antara empathy terhadap kepuasan pelanggan. Maksudnya jika empathy semakin baik maka semakin meningkatkan kepuasan pelanggan.

Koefisien regresi reliability bernilai positif. Berarti ada pengaruh positif antara reliability terhadap kepuasan pelanggan. Maksudnya jika reliability semakin baik maka semakin meningkatkan kepuasan pelanggan.

Koefisien regresi responsiveness bernilai positif. Berarti ada pengaruh positif antara responsiveness terhadap kepuasan pelanggan. Maksudnya jika responsiveness semakin baik maka semakin meningkatkan kepuasan pelanggan.

Koefisien regresi assurance bernilai positif. Berarti ada pengaruh positif antara assurance terhadap kepuasan pelanggan. Maksudnya jika assurance semakin baik maka semakin meningkatkan kepuasan pelanggan.

Berdasarkan tabel di atas maka juga dapat disimpulkan sebagai berikut :

1. Diperoleh nilai signifikansi lebih kecil dari alpha 0,05 yaitu $0,000<0,05$ untuk variabel tangibel. Berdasarkan analisis di atas disimpulkan bahwa tangibel berpengaruh positif signifikan terhadap kepuasan pelanggan.

2. Diperoleh nilai signifikansi lebih kecil dari alpha 0,05 yaitu $0,000<0,05$ untuk variabel Empathy. Berdasarkan analisis di atas disimpulkan bahwa Empathy berpengaruh positif signifikan terhadap kepuasan pelanggan.

3. Diperoleh nilai signifikansi lebih kecil dari alpha 0,05 yaitu $0,000<0,05$ untuk variabel Reliability. Berdasarkan analisis di atas disimpulkan bahwa Reliability berpengaruh positif signifikan terhadap kepuasan pelanggan.

4. Diperoleh nilai signifikansi lebih kecil dari alpha 0,05 yaitu $0,000<0,05$ untuk variabel Responsiveness. Berdasarkan analisis di atas disimpulkan bahwa Responsiveness berpengaruh positif signifikan terhadap kepuasan pelanggan.

5. Diperoleh nilai signifikansi lebih kecil dari alpha 0,05 yaitu $0,000<0,05$ untuk variabel Assurance. Berdasarkan analisis di atas disimpulkan bahwa 
Assurance berpengaruh positif signifikan terhadap kepuasan pelanggan

\section{Pembahasan}

\section{Pengaruh Tangible Terhadap Kepuasan Pelanggan}

Koefisien regresi tangible bernilai positif. Berarti ada pengaruh positif antara tangible terhadap kepuasan pelanggan. Maksudnya jika tangible semakin baik maka semakin meningkatkan kepuasan pelanggan. Berdasarkan hasil pengujian hipotesis menggunakan t-test, diperoleh nilai signifikansi lebih kecil dari alpha 0,05 yaitu $0,000<0,05$ untuk variabel tangibel. Berdasarkan analisis di atas disimpulkan bahwa tangibel berpengaruh positif signifikan terhadap kepuasan pelanggan.

Berdasarkan hal ini maka menurut asumsi peneliti terhadap penelitian ini adalah terbukti pada penelitian bahwa tangible berpengaruh positif signifikan terhadap kepuasan pelanggan JNE Cabang Ulak Karang Padang, dimana jika kualitas pelayanan dalam bentuk bukti fisik ditingkatkan maka kepuasan pelanggan juga akan meningkat. Dengan demikian, agar kepuasan pelanggan meningkat maka kualitas pelayanan juga harus ditingkatkan salah satunya dalam hal tangible /bukti fisik.

\section{Pengaruh Empathy Terhadap Kepuasan Pelanggan}

Koefisien regresi empathy bernilai positif. Berarti ada pengaruh positif antara empathy terhadap kepuasan pelanggan. Maksudnya jika empathy semakin baik maka semakin meningkatkan kepuasan pelanggan. Berdasarkan hasil pengujian hipotesis menggunakan t-test, diperoleh nilai signifikansi lebih kecil dari alpha 0,05 yaitu
$0,000<0,05$ untuk variabel Empathy. Berdasarkan analisis di atas disimpulkan bahwa Empathy berpengaruh positif signifikan terhadap kepuasan pelanggan.

Berdasarkan hal ini maka menurut asumsi peneliti terhadap penelitian ini adalah terbukti pada penelitian bahwa empati berpengaruh positif signifikan terhadap kepuasan pelanggan JNE Cabang Ulak Karang Padang, dimana jika mampu menunjukkan rasa empati yang lebih baik terhadap pelanggan maka pelanggan akan merasa nyaman sehingga kepuasan pelanggan juga akan meningkat. Dengan demikian, agar kepuasan pelanggan meningkat maka kualitas pelayanan juga harus ditingkatkan salah satunya dalam hal empati.

\section{Pengaruh Reliability Terhadap Kepuasan Pelanggan}

Koefisien regresi reliability bernilai positif. Berarti ada pengaruh positif antara reliability terhadap kepuasan pelanggan. Maksudnya jika reliability semakin baik maka semakin meningkatkan kepuasan pelanggan. Berdasarkan hasil pengujian hipotesis menggunakan t-test, diperoleh nilai signifikansi lebih kecil dari alpha 0,05 yaitu $0,000<0,05$ untuk variabel Reliability. Berdasarkan analisis di atas disimpulkan bahwa Reliability berpengaruh positif signifikan terhadap kepuasan pelanggan.

Berdasarkan hal ini maka menurut asumsi peneliti terhadap penelitian ini adalah terbukti pada penelitian bahwa reliability (keandalan) berpengaruh positif signifikan terhadap kepuasan pelanggan JNE Cabang Ulak Karang Padang, dimana jika mampu menunjukkan petugas JNE cukup handal dalam memberikan pelayanan 
maka pelanggan semakin percaya dengan kemampuan petugas dalam melayanai sehingga akan meningkatkan kepuasan terhadap pelanggan.

\section{Pengaruh Responsiveness Terhadap Kepuasan Pelanggan}

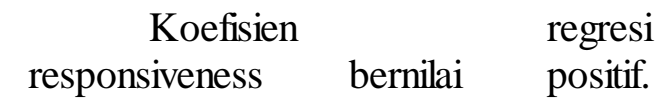
Berarti ada pengaruh positif antara responsiveness terhadap kepuasan pelanggan. Maksudnya jika responsiveness semakin baik maka semakin meningkatkan kepuasan pelanggan. Berdasarkan hasil pengujian hipotesis menggunakan t-test, diperoleh nilai signifikansi lebih kecil dari alpha 0,05 yaitu $0,000<0,05$ untuk variabel Responsiveness. Berdasarkan analisis di atas disimpulkan bahwa Responsiveness berpengaruh positif signifikan terhadap kepuasan pelanggan.

Berdasarkan hal ini maka menurut asumsi peneliti terhadap penelitian ini adalah terbukti pada penelitian bahwa responsiveness (daya tanggap) berpengaruh positif signifikan terhadap kepuasan pelanggan JNE Cabang Ulak Karang Padang, dimana jika petugas mampu memberikan respon yang baik terhadap pelanggan maka pelanggan akan merasa diperhatikan sehingga akan meningkatkan kepuasan terhadap pelanggan.

\section{Pengaruh Assurance Terhadap Kepuasan Pelanggan}

Koefisien regresi assurance bernilai positif. Berarti ada pengaruh positif antara assurance terhadap kepuasan pelanggan. Maksudnya jika assurance semakin baik maka semakin meningkatkan kepuasan pelanggan. Berdasarkan hasil pengujian hipotesis menggunakan t- test, diperoleh nilai signifikansi lebih kecil dari alpha 0,05 yaitu 0,000 $<0,05$ untuk variabel Assurance. Berdasarkan analisis di atas disimpulkan bahwa Assurance berpengaruh positif signifikan terhadap kepuasan pelanggan.

\section{B. Kesimpulan}

Berdasarkan hasil analisis data yang telah dilakukan dapat disimpulkan sebagai berikut:

1. Terdapat pengaruh positif signifikan antara tangible $\left(\mathrm{X}_{1}\right)$ terhadap kepuasan pelanggan (Y) JNE Cabang Ulak Karang Padang (koefesien regresi $=0.751$ dan $\mathrm{p}=0,000)$.

2. Terdapat pengaruh positif signifikan antara empathy $\left(\mathrm{X}_{2}\right)$ terhadap kepuasan pelanggan (Y) JNE Cabang Ulak Karang Padang (koefesien regresi $=0.342$ dan $\mathrm{p}=0,000)$.

3. Terdapat pengaruh positif signifikan antara reliability $\left(\mathrm{X}_{3}\right)$ terhadap kepuasan pelanggan (Y) JNE Cabang Ulak Karang Padang (koefesien regresi $=0.551$ dan $\mathrm{p}=0,000)$.

4. Terdapat pengaruh positif signifikan antara responsiveness $\left(\mathrm{X}_{4}\right)$ terhadap kepuasan pelanggan (Y) JNE Cabang Ulak Karang Padang (koefesien regresi $=1.037$ dan $p=0,000$ ).

5. Terdapat pengaruh positif signifikan antara assurance $\left(\mathrm{X}_{5}\right)$ terhadap kepuasan pelanggan (Y) JNE Cabang Ulak Karang Padang (koefesien regresi $=0.916$ dan $\mathrm{p}=0,000$ ) 
DAFTAR PUSTAKA

Agus, S. (2013). Pengaruh Promosi, Harga dan Inovasi Produk Terhadap Keputusan Pembelian Pada Batik Tulis Karang Melati Demak. Jornal.

Alma, B. (2004). Manajemen Pemasaran dan Pemasaran Jasa, Cetakan Kelima, Bandung : Alfabeta.

Arikunto, S. (2002). Prosedur Penelitian Suatu Pendekatan Praktek, PT. Rineka Cipta, Jakarta.

Dharmesta dan Irawan. (2005). Manajemen Pemasaran Modern, Edisi Kedua, Yogyakarta: Liberty.

Fernandes, Y. D., \& Marlius, D. (2018). Peranan Customer Service Dalam Meningkatkan Pelayanan Kepada Nasabah Pada PT. Bank Pembangunan Daerah Sumatera Barat Cabang Utama Padang. https://doi.org/10.31227/osf.io/wrh3p

Ghozali, I. (2011). Aplikasi Analisis Multivariate dengan Program IBM SPSS 20 (6th ed.). Semarang: Universitas Diponegoro.

Jasper. (2009). Kepuasan Pelanggan dan Price Acceptance (studi kasus pada penumpang penerbangan nasional), Jurnal Manajemen dan Akuntansi, Widya Mandala.

Kotler, P. (2000). Manajemen Pemasaran Indonesia, Alih Bahasa oleh Ancella Anitawati dan Hermawan, Edisi Pertama, Jakarta : Salemba Empat.

Lupiyoadi, R. (2011). Manajemen Pemasaran Jasa. Jakarta: Salemba Empat.

Marlius, D. (2018). Pengaruh Dimensi Kualitas Pelayanan Website Akademik Terhadap Kepuasan Mahasiswa Pada STIE “KBP”. Jurnal
Ipteks Terapan. Volume 12. No. 2. Hal. 116-128. http://doi.org/10.22216/jit.2018.v12i2 .633

Marlius, D. (2018). Loyalitas Nasabah Bank Nagari Syariah Cabang Bukittinggi Dilihat Dari Kualitas Pelayanan. Jurnal Pundi. Volume 1. No. $3 . \quad H a l .12-22$. https $/ /$ doi.org/10.31575/jp.v1 i3.60

Nur, D. J. (2016). Kualitas Pelayanan (Reliability, Responsiveness, Assurance, Emphaty, Tangibles ) Di Legend Premium Coffee Yogyakarta Program Studi Pendidikan Teknik Boga.

Soesanto, H. (2013). Analisis Pengaruh Pelayanan, Harga dan Fasilitas Terhadap Kepuasaan Pasien (Studi Pada Pasien Klinik As Syifa di Kab. Bekasi), 1-29.

Sugiyono. (2015). Metode Penelitian dan Pengembangan, Penerbit Alfabeta Bandung. Yogyakarta.

Sukmadinata. (2011). Metode Penelitian Pendidikan. Cetakan ke 7. Bandung: Remaja Rosdakarya.

Supranto. (2001). Pengukuran Tingkat Kepuasan Pelanggan: Untuk Menaikkan Pangsa Pasar. Rineka Cipta. Jakarta.

Susanti, F. W Ekazaputri. (2018). Service Performance Dan Kepuasan Sebagai Moderating Variabel Terhadap Loyalitas Nasabah Pada PT BPR Labuh Gunung Payakumbuh. Jurnal Benefita: Ekonomi Pembangunan Manajemen Bisnis Dan Akuntansi. Volume 3. No. 3. Hal. 433-444. http://doi.org/10.22216/jbe.v3i3.3472

Tjiptono, F. (2011). Strategi Pemasaran, Edisi ke-2, Andi Offset, Yogyakarta. 